\title{
Spiseforstyrrelser og selvmord
}

\author{
Ved Charlotte Buhl
}

\section{De siste 20-30 år er alvorlige og mindre alvorlige spiseforstyrrelser blitt mer utbredt, både blant barn, unge og voksne kvinner og menn. Vi er ogsa blitt mer oppmerksomme på disse lidelsene.}

Det er påvist at personer med spiseforstyrrelser har en signifikant $\varnothing$ ket risiko for fors $\varnothing \mathrm{kt}$ eller gjennomf $\varnothing \mathrm{rt}$ selvmord, og det rapporteres at selvmord kan utgjøre $50 \%$ av d $\varnothing$ deligheten i forbindelse med anorexia nervosa (Surgenor \& Snell 1998). Spiseforstyrrelser er også ofte i seg selv livstruende, og anorektikerens matvegring eller kamp mot sondefôring kan forstås som uttrykk for suicidale handlinger.

Med tanke på selvmordsforebygging er det viktig å bli klar over hvilke spesifikke aspekter ved spiseforstyrrelser som gjør at selvmordsrisikoen er betydelig, i hvilken grad og hvorfor denne risiko øker med langvarige eller kroniske tilstander av spiseforstyrrelser, og hvordan vi kan behandle spiseforstyrrelser og forebygge selvmord. Jeg skal kort fors $\varnothing$ ke å besvare disse spørsmålene og gi noen stikkord når det gjelder forebygging og behandling.

Våre kunnskaper om spiseforstyrrelser er i dag фkende. Vi kjenner de fysiske og psykologiske mekanismene som disse lidelsene innebærer, og vi vet at utvikling av spiseforstyrrelser har en viss sammenheng med samfunnsnormer og -idealer. Men årsaksforholdene er kompliserte, og vi vet ennå for lite om hva som forårsaker utvikling av anorexia nervosa, bulimia nervosa og tvangsspising. Vi vet etter hvert en del om hvordan vi kan behandle tilstandene, hvor alvorlig det å ha en spiseforstyrrelse kan være og hvor dårlig prognosen ofte er, særlig hvis pasienten ikke kommer tidlig til behandling.

\section{Flere typer spiseforstyrrelser}

Spiseforstyrrelsene er lidelser som innebærer forstyrret forhold til mat og spising, forstyrret kroppsforhold, og vanskeligheter knyttet til selvfølelse, følelsesliv og identitet (Buhl 1991). Som ordet spiseforstyrrelser sier, legger man vekt på de observerbare atferdstegnene eller symptomene når man skal stille diagnosen. De synlige sykdomstegnene er påfallende fordi de er knyttet til ageringer eller handlinger som den spiseforstyrrete person utfører, som å sulte seg, kaste opp, stadig trene, bruke store mengder vanndrivende eller avførende midler eller annet. Det kan være vanskelig å forstå at slike handlinger er ufrivillige når de samtidig er aktiviteter som på ett vis er viljestyrt.

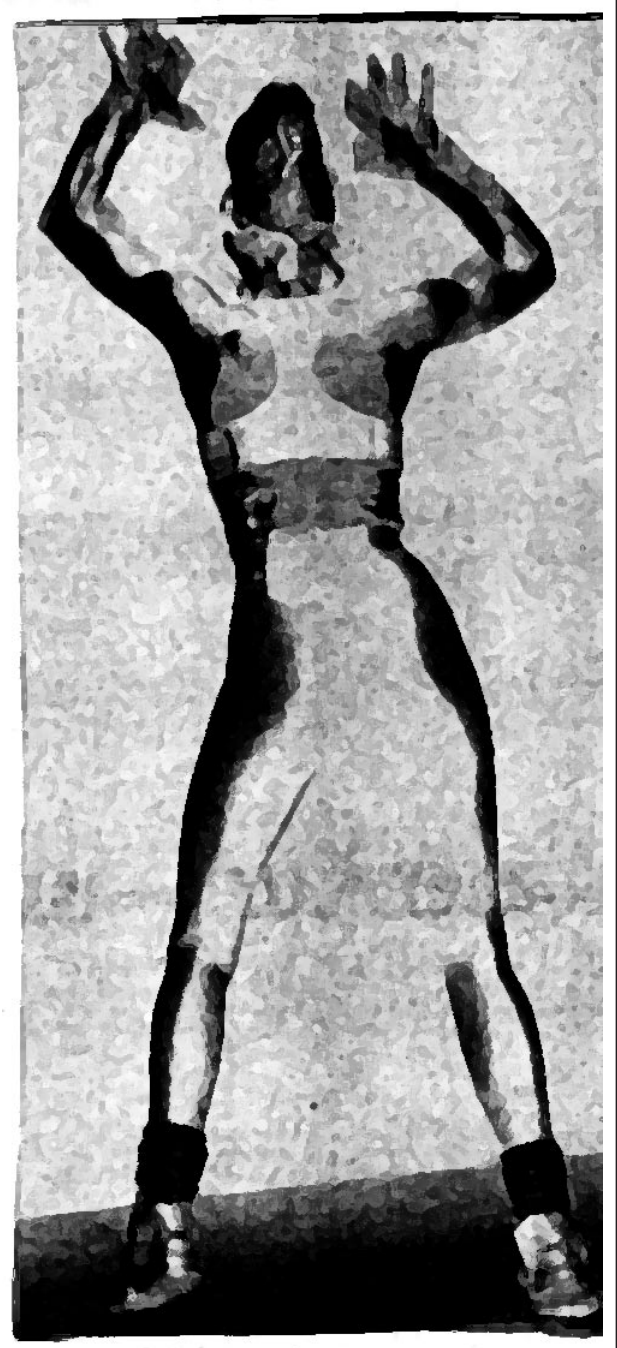

Spiseforstyrrelser inndeles i hovedsak i anorexia nervosa og bulimia nervosa. Det er store likheter, men også vesentlige ulikheter, mellom den anorektiske og den bulimiske person. Begge har et uheldig, ofte utilstrekkelig og ensidig matinntak, og selvfølelse og selvvurdering blir i overdreven grad basert på kroppens vekt. Begge фnsker å unngå å legge på seg og fors $\varnothing$ ker med forskjellige upassende og farlige metoder som oppkast, alvorlig misbruk av avføringsmidler og sulting å kompensere for det de spiser. Det er oftest den anorektiske pasient som tvangstrener, og den bulimiske pasient som i perioder mister kontrollen og kan spise store mengder.

Men disse sykdomstilstandene eller diagnosegruppene viser seg stadig mer sammensatte og kompliserte. I behandlings $\varnothing$ yemed er det n $\varnothing$ dvendig å differensiere mellom typisk og atypisk anorexia nervosa, mellom bulimisk og restriktiv anoreksi, og mellom anorektisk bulimi, tvangspreget og impulsiv bulimi.

Vi har også en tredje omfattende spiseforstyrrelse, tvangsspising (binge eating disorder), som minner mye om bulimia nervosa, men der den kompensatoriske atferden med oppkast eller periodesulting mangler. Denne pasientgruppen er stor, og både helsevesen og skoler møter nå hyppig pasienter med tvangsspising og svær overvekt (adipositas, obesity) (Buhl 1996).

\section{Forekomst og utbredelse}

Bulimia nervosa er langt mer utbredt enn anorexia nervosa. Sannsynligvis er det 10 ganger så mange med bulimi som anoreksi, og gruppen med tvangsspising er igjen st $\varnothing$ rre enn bulimigruppen. Det er flere kvinner (jenter) enn menn (gutter) med spiseforstyrrelser, forholdet kvinner-menn antas å være 10-1 for anorexia nervosa, 10-2? for bulimia nervosa. Men det er også store mørketall her. Vi vet at både leger, lærere og foreldre lett overser spiseforstyrrelser hos gutter og menn. Dette er bekymringsfullt både for behandlingsprognosen og ikke minst i forbindelse med selvmordsforebygging, fordi selvmordsraten blant unge menn er høyere enn for kvinner.

Spiseforstyrrelser debuterer vanligvis i 15-29-årsalderen, men kan også oppstå tidligere eller senere. $\varnothing$ kningen $\mathrm{i}$ insidensen, altså forekomst av nye tilfeller av sykdommene som vi har sett de siste 30 årene, har vært voldsom i den vestlige verden. For anorexia nervosa i aldersgrup- 
pen 15 til 25 år viser unders $\varnothing$ kelser 19,2 kasus pr 100.000 . For bulimia nervosa er det ennå gjort få undersøkelser.

Utbredelsen eller prevalensen i hele befolkningen for anorexia nervosa anslås til 0,3\%, for bulimia nervosa til 1\%, men utbredelsen er langt st $\varnothing$ rre i aldersgruppen 15-29 år. (Halmi 1997). Spiseforstyrrelser forekommer i alle sosiale og geografiske lag i befolkningen, og den tidligere forestilling om spiseforstyrrelser som noe som hovedsakelig forekom i $\varnothing$ konomisk overklasse ("Doctor's daughter's disease") eller kun i vår del av verden, er tilbakevist.

\section{Spiseforstyrrelser og personlighetsforstyrrelser}

Selv om det er atferden rundt spising som ligger til grunn for betegnelsen "spiseforstyrrelser", er tilstandene i utpreget grad uttrykk for forstyrret kroppsforhold, uvennskap og kamp mot kroppen, og er knyttet sammen med selvforakt, skamfølelse og depresjon (Buhl 1991). Erfaring med pasienter viser oss om og om igjen at konflikter som angår selvfølelse, følelsesliv og identitet, foreligger før de manifeste spiseforstyrrelsessymptomer utvikler seg. Utviklingen av en sykelig overopptatthet av vekten, forstyrret spising og

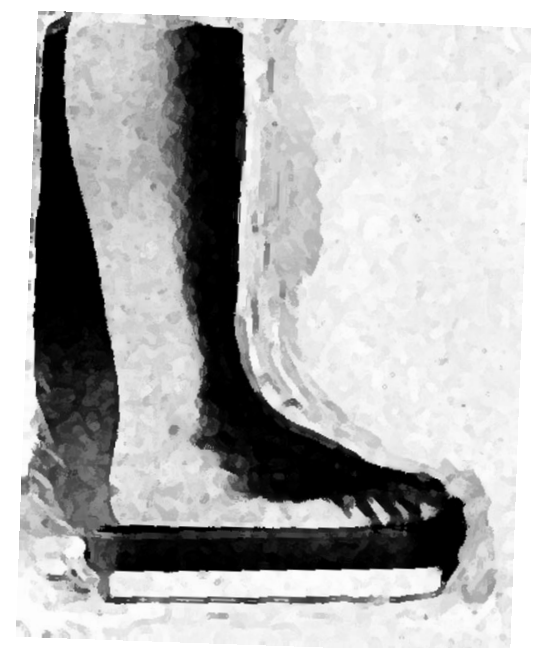

eventuell overdreven trening, oppkast eller annen kompensatorisk atferd, debuterer gjerne etter en lengre periode med følelser av hjelpeløshet, selvusikkerhet eller depresjon og faller hyppig sammen med tilbaketrekning fra vanlige sosiale aktiviteter.

Opplevelsen av følelsesmessig stress i forbindelse med biologiske eller sosiale endringer som medf $\varnothing$ rer $\varnothing \mathrm{kt}$ impuls- og affektpress, som puberteten, er vanlig. Men noen personer og miljøer søker å fjerne slike stressituasjoner med konkrete handlinger rettet mot det ytre, kroppen, og unngår å forholde seg til den indre følelsesmessige tilstand og opplevelse av usikkerhet, tristhet eller savn. Det er som de ikke har utviklet det språk som er nødvendig for å forstå egne impulser, kunne trøste seg selv og uttrykke og mestre indre emosjonell spenning. Emosjonelle situasjoner forblir dermed ubearbeidet og ufordøyet.

\section{Psykologiske instrumenter og deres funksjon}

Svikt i utviklingen av psykologiske instrumenter som er nødvendige for å regulere selvfølelse og affekter og for å håndtere impulser og følelser, er avgjørende for de personlighetsforstyrrelser som er sentrale i utviklingen av alvorlige spiseforstyrrelser, og i flere andre former for psykiske lidelser. De spesielle symptomene ved spiseforstyrrelsene, å sulte seg, overspise, kaste opp og tvangstrene, på samme måte som suicidalhandlinger og en rekke psykiatriske symptomer, kan forstås som fors $\varnothing \mathrm{k}$ på å unngå konflikter og uutholdelige situasjoner. Spiseforstyrrelsessymptomene blir dessuten fort selvforsterkende. De vedlikeholder og forverrer selve sykdomstilstanden, og som med selvmordshandlinger - de er selvdestruktive handlinger som man kan $\mathrm{d} \varnothing$ av.

Psykologiske instrumenter som er nødvendige for å møte og håndtere behov og impulser, dreier seg blant annet om evne til å bruke ord og abstrakte begreper, eller språk, som verkt $\varnothing y$ for å tolerere og differensiere indre fornemmelser og $f \varnothing$ lelser. Det handler om å kunne forstå seg selv, og om å kunne utvikle et variert indre og ytre handlingsrepertoar for å møte konflikter og utfordringer og indre stabilitet (stamina) og trygge grenser (egostyrke). Svikter dette blir man svært sårbar, man vil lett ty til utagering eller kortsiktige handlinger for å håndtere indre spenning og ubehag.

\section{Selvtrøst og depresjon}

Når man ikke har de psykologiske instrumenter for å tolerere og forstå seg selv, begrenses mulighetene til å trøste seg selv. En grunnleggende uro overfor følelser gir få muligheter til å skaffe seg lindring, og den indre verden kan fort bli fattig eller unyansert.

Den spiseforstyrrete mangler verkt $\varnothing y$, det indre emosjonelle språk, som bidrar til selvakseptering og til $\varnothing \mathrm{kt}$ forståelse og utholdenhet overfor tristhet og tomhet. Opptattheten av mat, sentral i spiseforstyrrelsens vesen, gjør at mange fors $\varnothing \mathrm{ker}$ å trøste seg og møte tomheten med mat.

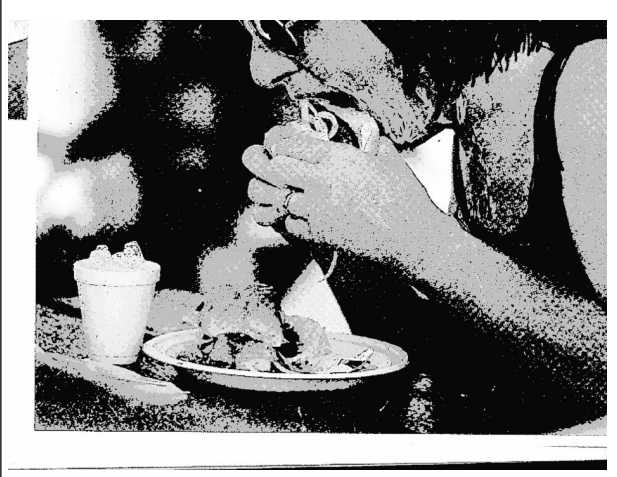

Bulimikeren og tvangsspiseren spiser mye eller ofte for å overdøve og drukne følelser, men angst og konflikter knyttet til dette gjør at maten ikke gir den ro og trøst som også er en vesentlig funksjon ved det å spise (Buhl 1996). Anorektikeren tillater seg hverken psykologisk eller materiell nødvendig næring av frykt for å vekke ytterligere sult og savn. Hun eller han fors $\varnothing$ ker å sulte bort lengsler, sinne og andre følelser. Mange med spiseforstyrrelser bruker også alkohol eller andre rusmidler for å dempe og fjerne noe som oppleves som ubehag, for å motvirke sult eller for å fors $\varnothing$ ke å glemme at kroppen er der.

En manglende evne til selvtrøst medfører at det blir vanskelig å utholde indre ensomhet og tomhet. Fravær av optimisme eller tro på at noe eller noen kan fylle tomheten, gjør at tanken på å $\varnothing \mathrm{de}-$ legge seg selv eller å ta sitt liv blir nærliggende. På mange måter kan man si at skillet mellom en alminnelig tristhet og en dyp depresjon ligger i dette grense- 
landet. Selv om personer med spiseforstyrrelser ikke nødvendigvis fremtrer som depressive, er deres symptomer uttrykk for utilstrekkelighetsf $\varnothing$ lelse og depresjon. Konfliktene knyttet til kroppsforhold og spising bidrar til at den anorektiske, bulimiske eller tvangsspisende kvinne eller mann blir deprimert og ulykkelig, særlig hvis hun eller han har hatt lidelsen i flere år. Jo lenger en person lider under en spiseforstyrrelse, jo sterkere blir depresjonen og jo mer uttalt blir tanker og $\varnothing$ nsker om å d $\varnothing$, og jo st $\varnothing$ rre er faren for suicidalfors $\varnothing \mathrm{k}$.

\section{Kropp og skam}

Det er ikke bare depresjon og manglende evne til selvtrøst som bidrar til pessimisme og suicidale tanker, men også overinvestering eller overopptatthet av kroppen og det grunnleggende fiendtlige forholdet til den. Sentralt i spiseforstyrrelser er opplevelsen av kroppen som en uregjerlig og grådig fiende som skal tynes (tynnes) og kontrolleres. For den spiseforstyrrete person oppleves grunnleggende drifter og impulser som sult, lengsel etter nærhet og seksualitet, savn og sinne, som truende og skambelagte. Det blir noe overveldende og ubegripelig som må unngås eller fjernes, med blant annet den virkning at kontakt med andre nære personer blir vanskeliggjort eller $\varnothing$ delagt.

Ensomhet eller savn av nær partner er noe som kjennetegner personer med spiseforstyrrelser, selv om dette ofte skjules bak en grei fasade. Bulimikeren kan være sosial når hun eller han er sammen med flere, den muntre og underholdende tvangsspiseren later som om hun eller han ikke plages av sin kropp og sine depresjoner, og anorektikeren er effektiv og arbeidsom på skole eller arbeidsplass. Mange skammer seg over ensomhet. Når personer med spiseforstyrrelser i tillegg skammer seg over sin kropp og sine følelser, og må holde dette skjult for omgivelsene, er de utsatt for store belastninger. $\mathrm{Vi}$ vet at slike situasjoner kan gjøre det lettere å gjennomf $\varnothing$ re selvdestruktive handlinger. Selvbeskadigelser er utbredt blant alvorlige spiseforstyrrete personer.

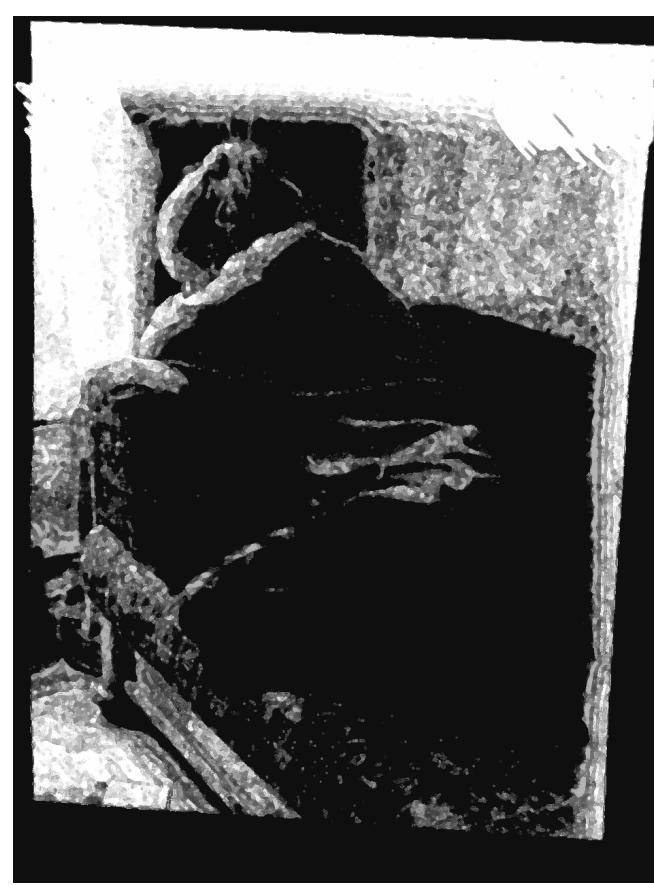

Kroppen angripes for å ødelegge og straffe den eller for å kjenne en smerte som kan overd $\varnothing$ ve andre følelser. Selvmordstanker fyller mye av tilværelsen, mange fors $\varnothing$ ker å utsette seg for ulykker eller livstruende situasjoner, og vi vet at suicidalhandlinger forekommer hyppig.

\section{Kontroll}

Den spiseforstyrrete personlighet innebærer ofte en tvangspreget struktur med liten indre frihet og differensiering.

Handlingsrepertoaret blir snevert og det psykologiske forsvaret unyansert. Kontrollapparatet fungerer primitivt, langs en "alt-eller-intet"-dimensjon, der kontroll og mestring betyr at man ikke skal kjenne noe tristhet, ingen savn overhodet, ikke sinne eller sult i det hele tatt. Personen opplever det som om alternativet til en slik absolutt kontroll er å la seg overskylle av følelser og behov som av en brottsjø, med totalt tap av mestring. Kontrollen fungerer etter prinsippet om svart eller hvitt, uten graderinger.

Slik kontroll er umulig, er ikke forenlig med et meningsfylt liv, og innebærer at enhver usikkerhet gir tap av selvaktelse, og skam og oppgitthet blir overveldende. Sammen med det indre handlingstrykk som kjennetegner spiseforstyrrelser (tilstandene er karakterisert av ageringer eller handlende symptomer) $\varnothing$ ker presset mot utholdenhet og kontroll av smertefulle impulser, og faren for destruktiv utagering blir stor. Vi ser da at destruktive symptomer $\varnothing \mathrm{ker}$, personen spiser enda mindre, kaster opp mer, eller skader seg selv fysisk på annen måte. Det er i slike situasjoner at faren for suicid er størst.

\section{Forebygging og behandling}

En vesentlig del av behandlingen av spiseforstyrrelser er å hindre de forskjellige destruktive utageringer og eskaleringen av de spise- og kroppsrelaterte symptomene og å stimulere utviklingen av mer nyanserte mestringsmåter. Det er nødvendig også å behandle den tilgrunnliggende utviklingsskjevheten eller personlighetsforstyrrelsen. Symptomrettet behandling og personlighetsrettet behandling bør gå hånd i hånd. Kun med hjelp til å forstå, tolerere og bearbeide savn, depresjon, sinne - og sult, kan destruktive utageringer, enten det er de spiserelaterte symptomer eller selvmordsfors $\varnothing \mathrm{k}$, dempes.

Kanskje det aller viktigste er at behandling igangsettes tidlig. Prognosen for anorexia nervosa og bulimia nervosa blir påtakelig dårligere jo lenger den spiseforstyrrete tilstanden vedvarer. Depresjonen og selvforakten blir mer alvorlig, og faren for selvmord $\varnothing$ ker.

\section{Litteratur}

Buhl C. Kampen om kroppen. Oslo: Universitetsforlaget 1991

Buhl C. Overvekt og slanking. Oslo: Universitetsforlaget 1996

Halmi K. Women and health. Eating disorders. Cornell University: Manus 1997

Surgenor L, Snell D. Nasogastric tube as a means of attempted suicide: a case report. European Eating Disorders Review 1998; 6: 212-215.

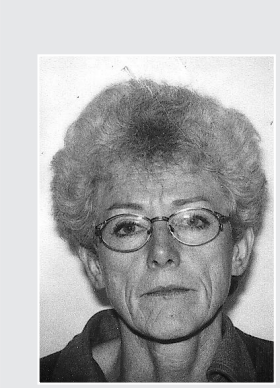

Charlotte Buhl er klinisk psykolog og spesialist $\mathrm{i}$ intensiv psykoterapi, og er selvstendig praktiserende psykoterapeut i Oslo. Hun har arbeidet med alvorlige spiseforstyrrelser $\mathrm{i}$ mange år, ledet det første statlige kompetansehevingsprogram i behandling av spiseforstyrrelser og har skrevet fagb $\varnothing$ ker og artikler om spiseforstyrrelser. 